\title{
New Policies to Fight Inflation: Sources of Skepticism
}

A NUMBER of proposals for new methods to fight inflation are being opposed, especially by labor organizations and the business community. Included among the old methods to fight inflation are restrictive monetary and fiscal policies, wage and price controls, and exhortation or "jawboning," all of which have been used in the United States at various times in the past thirty years. Among the new methods are reductions in excise, sales, and payroll taxes; tax-based incomes policies (TIPs); and deregulation, or the elimination of "sacred cows." This paper explores possible reasons for opposition to these more recent proposals, with major attention devoted to TIPs.

The existence of opposition is well known, but little explanation for it has appeared on the record. When considering objections to a proposed policy, it is important to keep in mind that not all objections are consistent with one another. For example, some emphasize reasons why a proposed policy might not work, and others point out possible adverse consequences if it does work. These two kinds of objections cannot be valid simultaneously, but it might not be possible to determine in advance which to take more seriously.

It is far easier to list objections to a proposed policy than it is to advance a better one. For this reason I do not attempt to distinguish be-

Note: I am indebted to Daniel Quinn Mills and participants of the Brookings Panel for helpful comments on an earlier version of this paper. 
tween two alternative purposes of the objections discussed. They can be viewed either as grounds for rejecting a policy altogether or as points to be considered in trying to improve the proposals under discussion and make them more workable.

\section{Excise and Payroll Tax Reduction}

Sales and excise taxes, unlike income taxes, enter directly into the measurement of consumer prices. A reduction in these taxes therefore produces a one-time reduction in the price level. ${ }^{1}$ Although this will not offset a continuing source of inflation such as an overly expansive monetary policy, it has an effect opposite to that of the unique events that have helped to raise the price level in recent years, such as the formation of the oil cartel by the Organization of Petroleum Exporting Countries.

Unlike some of the policies discussed below, reductions in excise taxes should be highly acceptable to both business and labor. For example, the reduction in the excise tax on telephone service proposed by President Carter in January 1978 is clearly directly beneficial to the telephone companies, their employees, and the communication workers' union. Even if the reduction were entirely passed on to consumers through lower rates, it would increase the quantity of telephone services demanded and therefore the demand for labor in the telephone industry.

The support of such tax reductions by business and labor should also extend beyond the industries directly affected. The labor movement generally regards income taxes as more equitable than excise taxes because they are progressive rather than regressive. Businessmen often favor cutting taxes whenever possible in the hope that this will eventually result in a corresponding restraint on government expenditures, much of which they may regard as wasteful.

The reduction of excise taxes to lower prices raises a number of prob-

1. By one-time changes in prices I do not mean to suggest that the events that give rise to them have no secondary effects. A reduction in excise taxes could have secondary effects through the operation of cost-of-living escalator provisions or through a moderating influence on newly negotiated wage settlements. The term "one-time" is intended to mean that such secondary effects will have a tendency to diminish in amplitude and eventually will die out. For a more precise statement of the effect of a onetime reduction in prices on the subsequent rate of inflation, see the comments on the Crandall paper in this volume by Edward Gramlich. 
lems. The federal government has few excise taxes remaining that can be reduced, and the important ones (gasoline, liquor, and tobacco) can all be defended on special grounds. An alternative proposal is to induce states and localities to reduce sales taxes by replacing the lost revenues with federal funds. The problems of this proposal lie in the area of intergovernmental relations rather than in relations between the government and private sectors-an area that will not be explored here.

A reduction in payroll taxes will also tend to produce a one-time reduction in the price level to the extent that the costs of payroll taxes are passed forward in the price of products, and this pass-through is probably substantial. A modest proposal of this sort was made by President Carter in January 1977 when he proposed a small reduction in the federal payroll tax for unemployment insurance. Much more ambitious proposals have been introduced in Congress, which would shift the financing of the Medicare and disability insurance programs from payroll taxes to general revenues. These proposals are favorable to the economic interests of unions and corporations and to most low-income individual taxpayers for whom payroll taxes are more important than personal income taxes. However, unless the cost of the programs being financed is reduced, the proposals will either require an increase in personal income taxes or a smaller decrease than would otherwise be possible. It is difficult to predict the reaction of business leaders to proposals that would benefit their corporations at some possible cost to them as individual taxpayers. The cost may be small, inasmuch as current proposals for reducing individual income taxes do not greatly affect those in high tax brackets.

It is not obvious that it would be possible to lower the price level by reducing payroll taxes and to restore the lost revenue by increasing corporate income taxes or by decreasing them less. Corporate taxes may also be passed forward to consumers to a considerable extent, and not enough is known about tax incidence to predict how much different the passthrough to prices is for the corporate tax and for the payroll tax.

\section{Tax-Based Incomes Policies}

Tax-based incomes policies (TIPs) have been discussed for a number of years, but recently have received wider attention and support. The earliest and most prominent among these policies is the Wallich-Weintraub 
proposal to increase the corporate income tax rate for corporations whose wage increases exceed a specified guideline. ${ }^{2}$ More recent proposals differ from Wallich-Weintraub by suggesting tax incentives for compliance with both price and wage guidelines and by suggesting tax reductions to corporations and workers in place of or in addition to tax increases. Some of these proposals were considered by Wallich and Weintraub, who regarded them as less desirable than their own.

The general attitude of business and labor toward the TIP proposals reminds one of the famous New Yorker cartoon in which a mother is trying to persuade a small girl to eat her broccoli, and the girl replies, "I say it's spinach and to hell with it." Business and labor are now firmly opposed to wage and price controls, and they consider TIP as another form of control. In the sections that follow, I explore some of the similarities and differences between TIPs and controls from the perspective of labor and management.

\section{SCOPE AND COVERAGE}

The Wallich-Weintraub proposal would apply to all corporations paying corporate income tax, with a possible exemption for small corporations. This is a far narrower scope than that of the wage controls in effect during the period 1971-74; those controls covered partnerships and proprietorships, state and local governments, and nonprofit institutions. The last two of these have been areas of rapid growth of unionism and collective bargaining in recent years. It is quite possible that in the future strong pressures for wage increases could originate in the unions of the public sector. This appears to have happened in Canada in recent years; the level of wage settlements there has exceeded that in the United States, despite the fact that workers in the private sector in the two countries are largely represented by the same set of unions.

The exemption for small firms and the exclusion of unincorporated business would exclude from coverage many firms in construction and trucking, which are industries with both high wages and strong unions.

2. : $\rightarrow$ Henry C. Wallich and Sidney Weintraub, "A Tax-Based Incomes Policy," Journal of Economic Issues, vol. 5 (June 1971), pp. 1-19. Similar proposals previously had been advanced by the two authors separately. See Wallich, "Can We Stop Inflation without a Recession?" Newsweek, vol. 68 (September 5, 1966), pp. 72-73, and Weintraub, "An Incomes Policy to Stop Inflation," Lloyds Bank Review, no. 99 (January 1971), pp. 1-12. 
Wallich has suggested that special policies to restrain wages might be needed for these industries. Unfortunately, he has not stated what these policies would be. The exclusion of trucking would be especially important because the International Brotherhood of Teamsters is the largest and one of the strongest unions in the United States, and its master freight agreement has an important pattern-setting influence beyond trucking, especially in food wholesaling and retailing. More generally, the exemption for small firms could lead to spillovers of wage increases from small firms to larger ones, or could lead to distortions of relative wages.

One supporter of TIP, Laurence Seidman, has proposed an exemption for "very low-paid" workers, without specifying how those workers would be defined. ${ }^{3}$ Past experience shows that such an exemption would have strong support in Congress, but could seriously diminish the effectiveness of TIP. For example, the 1973 extension of the Economic Stabilization Act exempted low-wage workers from wage controls effective May 1, 1973 , and defined them as those earning less than $\$ 3.50$ an hour. ${ }^{4}$ In May 1973 , all production and nonsupervisory workers in private nonagricultural employment were receiving average hourly earnings of $\$ 3.85$, so that almost half of this group was excluded from wage controls by this exemption.

It should also be recognized that TIP would not apply to those large private corporations that have no tax liability because they are not profitable in a particular year or because they carry forward tax credits. A union such as the retail clerks or the meatcutters negotiating under TIP with several supermarket chains in the same geographical area might choose to make a pattern-setting agreement with an unprofitable chain, which has no tax disincentive applicable to wage increases above the guideline and has the least financial ability to resist a strike. The union could then confront the profitable chains with a newly established wage rate, and it would be difficult for them not to match it.

Some advocates of TIP may feel that the concentration of penalties on profitable firms is desirable because high profits encourage large wage increases. Little solid evidence exists to support this view, however. In such industries as railroads and shipping, unions have bargained for and

3. Laurence S. Seidman, "To Fight Inflation," New York Times, December 22, 1976, p. 29.

4. U.S. Department of the Treasury, Office of Economic Stabilization, Historical Working Papers on the Economic Stabilization Program, August 15, 1971 to April 30, 1974 (Government Printing Office, 1974), pt. 1, p. 347. 
won high wages and costly manning requirements not only from unprofitable firms, but even from bankrupt ones.

The scope of the Wallich-Weintraub proposal could be greatly extended by applying the tax penalty to payroll taxes rather than to corporate income taxes. It would then include unincorporated businesses, corporations with no tax liability, nonprofit institutions, and those state and local governments that participate in the social security system.

Wallich and Weintraub argue against the use of payroll taxes for TIP on the ground that those taxes are more likely to be passed forward in prices than are corporate income taxes. It is easier for me to agree that payroll taxes are passed forward than to accept the view that corporate income taxes are not. If one corporation in a competitive industry negotiated a wage increase above the guideline established by TIP and paid the resulting corporate income tax penalty, the firm would have difficulty passing the penalty forward because its competitors would have both lower wage costs and lower taxes. In some cases, however, wage agreements are negotiated with entire industries, such as basic steel. In others, such as automobiles, an agreement reached with one major producer is extended to the others with little or no change. If in such cases one firm reaches a wage agreement that exceeds the guideline and results in tax penalties, it might set higher prices to restore in large part the previous rate of return on capital after taxes. Both the wage increase and the price increase would then probably be followed by other firms in the industry. Indeed, in industries where demand for a product is relatively inelastic, the only major barrier to such an outcome would seem to be foreign competition. For TIP to be effective in industries characterized both by price leadership and by industry-wide bargaining or pattern-following in wages, guidelines and penalties would be required for excessive price increases. Such proposals are discussed below.

Another difference between the use of corporate income taxes and payroll taxes as a base for TIP is that the penalty rates of payroll taxes would augment the effect of higher wages in inducing the substitution of capital for labor. The use of corporate income taxes would presumably not induce factor substitution or, if anything, would cause substitution of labor for capital.

The Wallich-Weintraub proposal is limited to wages because its proponents believe that markups of prices over unit labor costs are historically quite stable. In Weintraub's words, TIP "presupposes that the wage- 
productivity nexus is crucial in inflation." 5 Thus, in Weintraub's view, postwar inflation has been essentially wage-push inflation. Needless to say, the unions (among others) vigorously disagree with this view; they would point to the rises in prices of raw agricultural commodities and imported petroleum and to the devaluation of the dollar since 1971 as contributors to inflation for which they bear no responsibility. They regard the Wallich-Weintraub proposal as completely one-sided and therefore unfair to labor. Although unions are opposed to any kind of incomes policy, they are most strongly opposed to one that focuses exclusively on wages. They would fight its enactment by the Congress with as much force as an aroused labor movement can muster, which is considerable.

The view that price inflation merely mirrors wage inflation has been somewhat shaken by the events of recent years. From 1973 to 1974 the consumer price index rose 11.0 percent, while average hourly earnings in private nonagricultural industry rose only 8.2 percent, producing a decline of 2.5 percent in real hourly earnings. Although the events of 1974 were highly unusual, the labor movement certainly cannot be blamed for wanting insurance against their repetition (which is not to say that they necessarily should have it) ${ }^{6}$

\section{ESTABLISHING THE GUIDELINE}

The problem of establishing an appropriate wage guideline is not much different under TIP than it is under wage controls, but this does not mean that it is unimportant. Perhaps the principal difference is that TIP necessarily involves an explicit guideline, while wage controls do not. The Construction Industry Stabilization Committee, the most successful of the wage-control bodies of the 1971-74 period, operated without an explicit wage guideline throughout its existence.

Labor unions oppose a wage guideline in part because they fear that it might be unfairly set or that it would not be appropriately modified to changing conditions. Both concerns are based on past experience.

Wallich and Weintraub suggest a wage guideline that could be estab-

5. Sidney Weintraub, "Incomes Policy: Completing the Stabilization Triangle," Journal of Economic Issues, vol. 6 (December 1972), p. 119.

6. Some analysts would prefer to use compensation per hour of labor in the private sector for this kind of analysis. However, the unions focus on the hourly earnings of production and nonsupervisory workers because they have few members in the private sector who are salaried employees. 
lished at some point between a minimum equal to the trend of output per labor hour and a maximum equal to this trend plus the initial rate of inflation. ${ }^{7}$ Their minimum is the same as the wage guideline established by the Kennedy administration in 1962, and could be used in a situation in which the initial rate of inflation was zero or close to it. Even under these circumstances, this guideline is not acceptable to the labor movement. It is well known that increasing wages in proportion to output per labor hour will keep constant the labor and nonlabor shares of output and income. In other words, this guideline freezes the functional distribution of income. Historically, however, there has been a tendency for labor's share of income to rise gradually through time, even after adjustment for the decline in self-employment. ${ }^{8}$ Understandably, labor does not want this historical trend that is favorable to its constituents brought to a halt, not even temporarily.

A rough check on whether guidelines actually had this effect on labor's share is afforded by computing the compensation of employees as a percentage of national income for selected years. This figure was 71.6 in 1961 before the Kennedy guidelines and 70.6 in 1966; it was 76.3 in 1970 before the Nixon controls and 75.1 in 1973. I would ascribe the declines in labor's share during the periods of guidelines and controls to the business cycle rather than to incomes policy. However, the sharp rise in labor's share during the intervening period when there was no incomes policy is also noteworthy. In any event, the labor movement is not likely to draw favorable conclusions about guidelines from these figures.

The opposite extreme in the range of possible wage guidelines of the Wallich-Weintraub proposal would surely not be acceptable to business. To allow wages to increase by the trend of productivity plus a full allowance for inflation is to allow labor larger gains than it has been able to win in the period since mid-1974, when there have been no guidelines. If we accept 2 percent as a rough estimate of the trend of productivity, real hourly earnings of all employees in the private nonagricultural sector have not risen as much as this trend since 1972. A guideline of productivity plus a full allowance for inflation therefore seem more likely to accelerate wage increases than to retard them.

7. "A Tax-Based Incomes Policy," p. 12.

8. See Irving B. Kravis, "Income Distribution: Functional Share," in David L. Sills, ed., International Encyclopedia of the Social Sciences, vol. 7 (Macmillan, 1968), pp. 132-45. 
Intermediate positions, such as the trend of productivity plus half the rate of inflation, seem superior to the extremes, but even these have substantial difficulties. If the initial rate of inflation were 6 percent and the trend of productivity 2 percent, a wage guideline of 5 percent would result. If such a guideline were enforced, real output per labor hour could rise at a rate of 2 percent a year, and real wages would initially fall 1 percent a year-an outcome totally unacceptable to the unions. Eventually the rate of inflation should decline to 3 percent if the program is successful, but the unions might not be patient enough to wait for this. Moreover, at this point the wage guideline would be reduced to 3.5 percent, again producing a real wage gain much lower than the trend of productivity. Only in some final equilibrium where prices are not rising at all do real wages rise with the productivity trend.

I conclude that if there is to be a wage guideline acceptable to unions, it cannot include a constant allowance for ongoing inflation, but may need to adjust that allowance each year. Formulas based on theoretical considerations may be inferior to more arbitrary ones based on simple deceleration from existing rates of increase in compensation. For the guideline to be acceptable and fair, it must allow for growth in real wages. For the guideline to have any effect in restraining inflation, it must be less than the wage increases that would occur in its absence. It is not clear that a number always exists that meets both of these constraints; indeed, it is not even clear that one exists at present.

Labor's fear that a guideline might become less favorable to the interests of workers over time is supported by the events of both 1962-67 and 1971-74. When the Kennedy administration adopted wage guidelines based on productivity in 1962 , the trend of productivity change was substantially above the rise in consumer prices, so that a guideline based solely on productivity provided for considerable growth in real wages. By 1966, the guideline had become a specific number-3.2 percent a year. During 1966, as the Council of Economic Advisers noted in its January 1967 report, consumer prices rose 3.3 percent. Adherence to the guidelines therefore implied a slight fall in real wages. The council nevertheless did not change the guideline number. ${ }^{9}$

9. See Economic Report of the President, January 1967, pp. 127-29. Because the position of the council was somewhat ambiguous, a direct quotation may be helpful: "The Council recognizes that the recent rise in living costs makes it unlikely that most collective bargaining settlements in 1967 will fully conform to the trend 
A second aspect of the 1966-67 guidelines was also disturbing to the labor movement. The 3.2 percent figure that became the wage guideline was the latest average of the increase in output per labor hour in the private sector for the five-year periods ending in 1963 and in 1964, as measured at the end of those years. For the five years ending in 1965, the corresponding figure was 3.4 percent. In its January 1966 report the council did not accept this higher figure as a basis for revising the guideline on the ground that five consecutive years of economic expansion had created a productivity gain that was above the long-term trend. $.^{10} \mathrm{Al}-$ though this belated recognition that five years is too short a period to establish a trend was probably correct, the unions were offended because the rules had been changed in the middle of the game. Their sense of grievance, oddly enough, existed although-according to knowledgeable observers of collective bargaining - the guidelines had little or no effect in restraining negotiated wage settlements. ${ }^{11}$

The 1962-66 experience was repeated in 1971-74. In November 1971 the Pay Board set the general pay standard for the new wage control program at 5.5 percent. This was widely interpreted as based on a combination of the long-run productivity trend and a portion of the current increase in consumer prices. The productivity trend was then about 3 percent a year, and the controls program was expected to reduce the rate of inflation to 2.5 percent by the end of 1972 . A 5.5 percent wage standard minus a 3.0 percent productivity trend implies a 2.5 percent rate of increase of unit labor costs, which is consistent with an equal increase in prices. By 1973, however, the rate of increase of the consumer price index (December 1972 to December 1973) was 8.8 percent. Nevertheless, the 5.5 percent wage standard was never formally abandoned during the controls programs, though exceptions to it became more and more numerous.

increase of productivity. But it sees no useful purpose to be served by suggesting some higher standard for wage increases, even on a temporary basis.

"The only valid and noninflationary standard for wage advances is the productivity principle. If price stability is eventually to be restored and maintained in a high-employment U.S. economy, wage settlements must once again conform to that standard" (p. 128).

10. Economic Report of the President, January 1966, p. 92.

11. See John T. Dunlop, "Guideposts, Wages, and Collective Bargaining," in George P. Shultz and Robert Z. Aliber, eds., Guidelines, Informal Controls, and the Market Place: Policy Choices in a Full Employment Economy (University of Chicago Press, 1966), p. 84. 
Those proponents of TIP who advocate tax penalties or bonuses based on both price increases and wage increases usually select a pair of guidelines that differ by the trend of output per labor hour. If this trend were 2 percent, they might propose a wage guideline of 6 percent and a price guideline of 4 percent. ${ }^{12}$ Such a pair of guidelines is consistent, on average across all industries, with unit labor costs rising as fast as the price guidelines.

The problems of establishing a price guideline, however, are much more formidable than those of setting a wage guideline. Okun suggests a "dollar-and-cents pass-through of any increases in costs of materials and supplies." 13 These costs would presumably differ according to the product, which would make departures from the price guideline difficult to detect. Moreover, the term "materials and supplies" may be overly narrow. Are corporations to absorb all increases above 4 percent in the costs of purchased services, such as legal and accounting fees, travel costs, and so on? But even if there were no increases in the costs of materials, supplies, and purchased services, a uniform price guideline would be unfair because the productivity trends of individual industries differ dramatically from that of the economy as a whole. It is reasonable to state that workers doing the same work in different industries should receive roughly the same pay regardless of industry differences in productivity, but it is altogether unreasonable to assume that the prices of the products of industries with different productivity trends should move together.

For the period 1970-75 the average growth in output per production worker hour in the industries for which separate measures are published by the Bureau of Labor Statistics ranged from an increase of 9.2 percent in candy and other confectionery products to a decrease of 4.8 percent in bituminous coal and lignite mining. ${ }^{14}$ An industry that experiences no change in productivity and has a 6 percent increase in wages will be forced to raise prices at close to 6 percent unless it uses little labor. An industry whose productivity is rising at 8 percent should be reducing product prices unless its nonlabor costs are rising rapidly. A price-control agency with discretionary authority can take such circumstances into account to

12. See Arthur M. Okun, "The Great Stagflation Swamp," Challenge, vol. 20 (November/December 1977), p. 13.

13. Ibid.

14. U.S. Bureau of Labor Statistics, Productivity Indexes for Selected Industries, 1976 Edition, bulletin 1938 (Government Printing Office, 1977), table 1. 
the extent that available data permit, but it is almost impossible to write them into the Internal Revenue Code.

\section{COLLECTIVE BARGAINING AND INDUSTRIAL DISPUTES}

The proposal to tax corporations on excessive wage increases must consider the differences between tax units and collective bargaining units. A corporation might treat all its domestic operations as one entity for corporate tax purposes, but within this entity it might have many different collective bargaining units, often represented by several different unions, as well as a large number of nonunion employees.

Weintraub attempts to convert this problem into an asset, in my opinion unsuccessfully. He writes, "A not inconsiderable virtue [of TIP] is that unions can bargain for sums in excess of the productivity norm and perhaps succeed in redistributing some income from profits and managerial employees." 15 This is a clear statement of why business might oppose TIP.

Even if the goal of policy were to redistribute income by differential changes in compensation to create greater equality, it could not be achieved by the route that Weintraub suggests. Nonunion employees are not all managers. In most firms, the majority of nonunion employees are clerical workers, and they generally receive lower wages than unionized production workers. Suppose that a firm had equal numbers of union and nonunion employees, that the wage norm was 6 percent, and that the union succeeded in obtaining a wage increase of 8 percent. To avoid a tax penalty, the firm would have to hold its nonunion employees to a 4 percent wage increase. If firms chose to do this, there would be an increase in union-nonunion wage differentials, which are already large; many economists might say they are too large. However, in my judgment few employers would risk such a policy. To provide nonunion workers with only half the wage increase of union workers would lower morale and perhaps decrease productivity or invite the unionization of the nonunion group. Most firms would prefer to pay the tax penalty. But if they did, the effectiveness of TIP would be reduced. The unions, however, could and probably would use Weintraub's argument as grounds for not adhering to the wage norm.

The same kind of problem arises when a company bargains with two unions of unequal strength. If the stronger union negotiated first, it might

15. "Incomes Policy: Completing the Stabilization Triangle," p. 119. 
insist on a settlement in excess of the guideline, and the employer would have to decide whether to pay the tax penalty or to try to reach a settlement below the guideline with the weaker union. However, the existence of a wage guideline makes it more difficult for a weak union to accept a settlement below the guideline.

The general strategy of the Wallich-Weintraub proposal is to "stiffen the backbone" of employers in wage bargaining - that is, to encourage employers to resist excessive union wage demands. It seems logical that this will increase both the frequency and the duration of strikes, and the Wallich-Weintraub analysis explicitly suggests the latter effect. In the diagram below, which is a slight simplification of a similar one used by Wallich and Weintraub, the horizontal axis measures time, and the vertical axis measures the rate of change of money wages. Point $D$ is the union's original wage demand, and the line labeled $U$ represents the union's modification of its wage demands through time. The line $E$ shows the improvement of the employer's wage offer through time without TIP. The introduction of such a policy, with the wage guideline established at point $G$, shifts the righthand portion of the employer's offer curve to $E^{T}$. Without TIP, settlement is reached at point $S_{o}$ at time $T_{0}$; after the introduction of TIP, settlement is reached at point $S_{1}$ at time $T_{1}$. Wallich and Weintraub do not divide their time scale into two segments representing negotiations before and negotiations during a strike. However, if a strike began before $T_{0}$, it would be prolonged by the time between $T_{0}$ and $T_{1}$. Presumably some strikes would also begin in this interval.

Business and labor generally prefer to avoid strikes whenever possible because of the losses they bring to both parties. This aspect of TIP gives them additional reason to oppose the policy. Strikes also impose losses on the general public, and the shortages that result from them can lower productivity and raise prices.

In this respect, TIP is inferior to wage controls, which actually reduce strikes. Days idle resulting from work stoppages were 0.15 percent of total working time in 1972 and 0.14 percent in 1973, the two years in the past decade in which wage controls were in effect throughout the year. These figures are below those for any other years in this decade, including the recession year, 1975. It is easy to understand why controls deter strikesthere is not much point in a union placing economic pressure on an employer to make wage concessions if the government will not permit these concessions to go into effect.

It is crucial to the Wallich-Weintraub analysis that union demands 


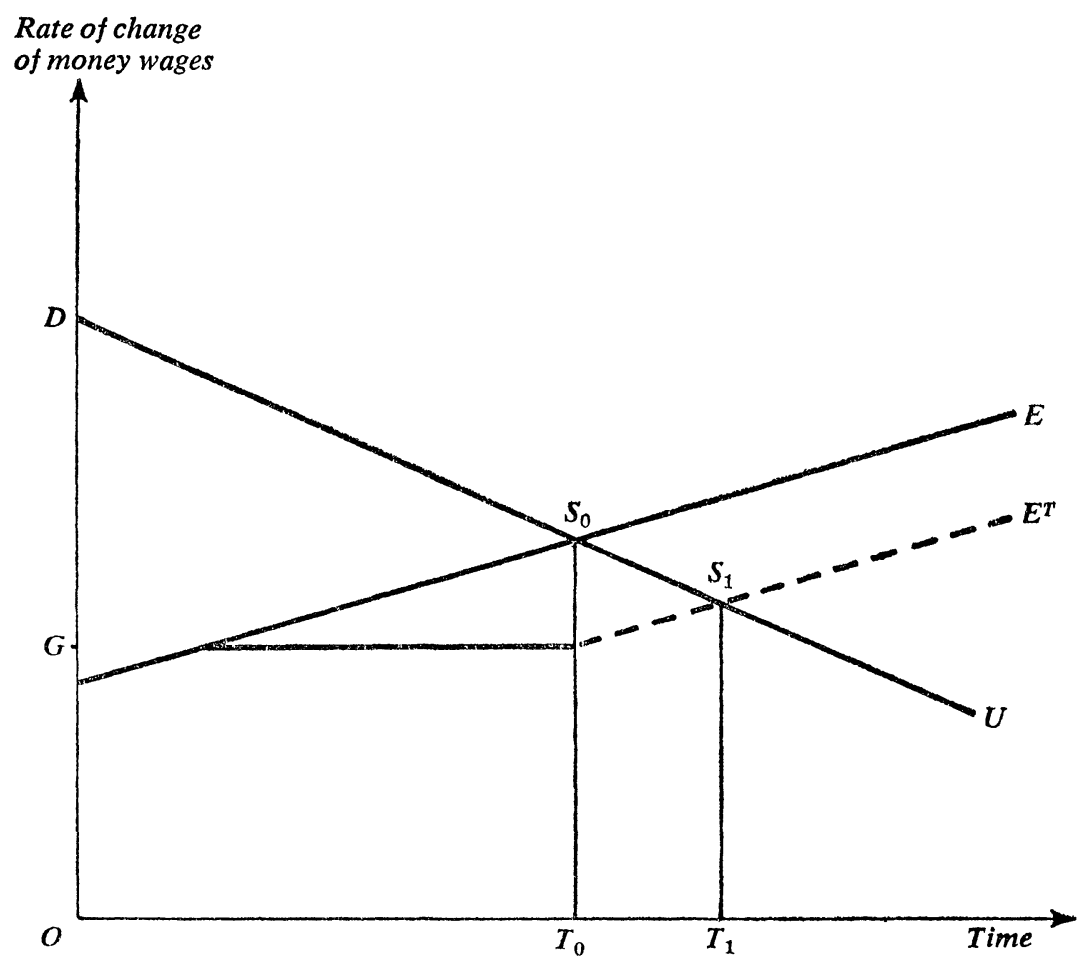

decline consistently through time, although it is by no means obvious that they will. The union may have some minimum demand for which it is prepared to bargain to the point of impasse or even to strike for a protracted period. In the diagram this would be shown by a horizontal segment of $U$. If this horizontal segment began at or to the left of $S_{0}$, TIP would increase the frequency or length of strikes without any reduction in the wage increase at which they were settled. Wallich and Weintraub recognize this possibility, but argue that a union that fails to take account of TIP in its demands is not maximizing benefits for its members.

I know of no evidence that industrial disputes arise from or are settled by maximizing behavior by both parties, any more than are international or religious disputes. It is not unknown for a strike to be settled for more than the union's original demand when a strong union is determined to teach management a lesson and recoup some of the losses suffered during a strike. When the union has the power to win a long strike, it does little good to strengthen management's backbone. There will certainly be some 
cases in which the TIP guideline would cause the size of the eventual settlement to be smaller. But this would not be true of every settlement, and it is an open question whether the gains would be worth the costs.

One advantage claimed for TIP is that it is automatic and thus easy to administer. The opposite side of this coin is that TIP does not enable its administrators to help in the settlement of actual or potential disputes in collective bargaining or in the improvement of collective bargaining structures. There have been cases in which the administration of wage controls accomplished this in the past, and this has been one of the mitigating aspects of wage-control programs.

If TIP does lead to more strikes, it could also lead to more government intervention to settle those strikes. Such intervention usually brings pressure on management to offer more generous terms because there may be no way in which the government can bring effective pressure on union members. The federal government would then either have to work at cross-purposes with its own TIP or suspend the TIP to help settle emergency disputes.

\section{ADMINISTRATIVE PROBLEMS: WAGES ${ }^{16}$}

As I noted earlier, one of the principal claims made for the TIP proposals is that they do not involve substantial administrative costs. Laurence Seidman, in his letter to the New York Times of December 22, 1976 , lists as TIP's first advantage over controls that "no new bureaucracy is required." Critics of the TIP proposals have been skeptical of this claim. Gardner Ackley has commented, "From my experience in designing and administering price controls during World War II, and again, in a policy role, during the Korean War, I retain keen, and sometimes bitter, memories of great ideas about ways to restrain wage and price increases for which the fine print could never be written-or if it could be written, filled endless volumes of the Federal Register with constant revisions, exceptions, and adjustments necessary to cover special situations that could never have been dreamed of in advance by the most imaginative economists, accountants, and lawyers." ${ }^{" 17}$ This section explores the basis for these diverging views.

16. Some of the problems raised in this and the following section are considered in more detail in the paper in this volume by Larry L. Dildine and Emil M. Sunley.

17. Gardner Ackley, "Okun's New Tax-Based Incomes-Policy Proposal," Economic Outlook, USA, vol. 5 (Winter 1978), p. 8. 
The difficulty of administering wage guidelines depends in part on how increases in compensation are defined. Originally, Wallich and Weintraub proposed four possibilities: (1) total wages, salaries, bonuses, and fringe benefits divided by the number of employees on a given date; (2) total wage and related payments divided by the daily average number of employees; (3) total wage and related payments divided by employee hours worked (that is, compensation per employee hour); and (4) total wage and related payments in each job classification and grade divided by the number of man-hours worked, combined into a weighted index of wage increases. ${ }^{18}$

Wallich and Weintraub recognized that the first three of these proposals were subject to possible manipulation by the employer or could result in windfall gains and losses through changes in the skill mix. For example, an employer could increase wages by more than the guideline in every occupation, yet escape penalty taxes because employment or hours had increased most in the low-paid occupations. By March 1972, Wallich was writing that these proposals "probably will not do at all." 19 Yet Wallich and Weintraub also recognize that the fourth proposal involves substantial difficulties of computation for large firms with many establishments and hundreds of different job titles. Firms do not now ordinarily maintain weighted indexes of wage increases, and even the Bureau of Labor Statistics has only begun such an index in the past decade. Average hourly earnings are easily obtained by accountants from payroll records; weighted indexes of wage changes must be computed by statisticians. Neither the typical corporate employer nor the Internal Revenue Service has the capabilities of the Bureau of Labor Statistics in this area. Specifying the proper computation of a weighted index of compensation increases in TIP is a task that gives rise to the kind of fears that Ackley has expressed.

An area of difficulty in the administration of wage controls that would also be present in TIP is the treatment of fringe benefits. Costs of fringe benefits are easy to compute when employers make contributions of cents per hour to a benefit fund, as they do in the construction industry. They are difficult to estimate, however, when a collective bargaining agreement or an employer benefit plan specifies future pension or health bene-

18. Condensed from "A Tax-Based Incomes Policy," pp. 13-14.

19. Henry C. Wallich, "Phase II and the Proposal for a Tax-Oriented Incomes Policy," Review of Social Economy, vol. 30 (March 1972), p. 8. 
fits rather than current contributions. Translating such benefits into current costs requires complicated calculations about which competent actuaries can disagree. The Internal Revenue Service already faces these difficulties in auditing employer costs of fringe benefits claimed on tax returns.

Past wage-control programs have controlled benefits more loosely than wages and salaries. This can be justified if fringe benefits are believed to be too low as a proportion of total compensation, which may have been true during World War II and the Korean War. It could also be justified during a demand-pull inflation on the ground that future pensions and health benefits, unlike current wages, do not add to aggregate demand. However, the theory underlying TIP assumes that the problem is costpush, not demand-pull inflation. To be consistent with this theory, TIP advocates must fully include fringe benefits in their compensation measure.

The costs of fringe benefits can rise not only because benefit levels are improved, but also because inflation raises the cost of maintaining existing benefit levels. Such increased costs have been exempted from previous wage-control programs, but it is not at all clear that this could be permitted in a future incomes policy without seriously weakening the policy. ${ }^{20}$

Another area of administrative difficulty is the implementation of incentive pay programs. In most of these programs, an increase in pay resulting from higher output would nevertheless reduce unit labor costs. Because the main purpose of TIP is to contain the cost of labor per unit, this suggests that increases in amounts received as incentive pay under existing schemes should be excluded from the proposed wage index. However, past wage-control programs have regulated the introduction of new incentive pay schemes on the ground that a large loophole might be created if regulations were absent. Special consideration needs to be given to incentive programs for executives based on corporate and divisional profits rather than on output. None of these problems is by any means insurmountable, but addressing them requires regulations and administrative machinery.

The negotiation of cost-of-living escalator provisions will create an area of increased uncertainty for management under TIP; more than half

20. For an elaboration of this view, see Daniel Quinn Mills, Government, Labor, and Inflation: Wage Stabilization in the United States (University of Chicago Press, 1975), pp. 202-05. 
of all major collective bargaining agreements now contain such provisions. Any tax penalties arising from escalator provisions can be levied after the fact on the basis of wages actually paid. When negotiating the agreement, management must predict the future rate of inflation, as it does now. However, the possibility of a tax penalty will increase the cost of underprediction. This could restrain the spread of escalator provisions, but those managements already using them will not welcome the added risk.

Attention must also be paid to problems of wage inequities. During the wage-control program of $1971-74$, the base date for calculating wage increases was November 14, 1971. Collective bargaining agreements reached before that date were allowed to operate as negotiated unless challenged. Those reached afterward required approval if they exceeded the pay standard, and were often cut back. Situations then arose in which two groups of workers in the same local union who had always received the same wage rate would have different rates because one employer had signed an agreement on November 13 and another had signed an identical agreement on November 15; such differences created great unrest among union members and strong political pressures on union leaders. Some of these inequities were later remedied by awards of retroactive pay to the aggrieved workers. This solution was most distasteful to management, which had not included the originally disallowed wage increases in prices, and viewed retroactive payments as impinging directly on the bottom line of the profit and loss statement.

From a union's viewpoint, TIP is preferable to controls in preventing wage inequities from arising when the program is first instituted. By actual or threatened strikes, unions could compel most managements to follow the traditional patterns established in previously negotiated settlements, even at the cost of tax penalties. However, the inequity is shifted to the firm: the employer who follows patterns pays penalty taxes; the one who sets patterns does not. Again, regulations could be written and administered to address such problems, but not without the usual bureaucratic costs.

Multiyear agreements negotiated before the inauguration of a TIP give rise to a problem even if they do not cause wage inequities. If wage increases in the second and third years of such agreements exceed the guideline, employers could be liable for tax penalties that were unanticipated when they entered into the agreements. To avoid this effect, prior 
agreements could be exempted from TIP, but this would mean that TIP would need three years to become fully effective.

Not all distortion in wage structure arises from the operation of incomes policies. Some comes from the sequential nature of collective bargaining and wage determination in the private sector. Wage settlements elsewhere and changes in labor market conditions can create situations in which some wages in a firm are inequitably low or are different from prevailing rates in the area or industry. Wage-control programs have always included provisions for dealing with such inequity problems, usually administered by staff with experience in industrial relations. Such exceptions are less necessary under TIP than under wage controls because an employer can remedy inequities and pay the tax penalty without obtaining previous permission and without violating the law. However, if no exceptions were permitted, some employers would probably pay tax penalties resulting from circumstances essentially beyond their control.

The most difficult question for unions in past wage-control programs has been whether or not to participate in the administration of the program. If union leaders did not participate, they feared that the program would be administered in ways that were adverse to the interests of their members. If they did participate, they could be criticized by rivals within the union for holding wages down when they were being paid to raise them. The resulting ambivalence is shown by the several cases in which union leaders have walked out of wage stabilization boards-and sometimes have been persuaded to return by changes in the program. The best option that union leaders have at present is to try to prevent TIP from going into effect.

The threats to incumbent union leaders from rivals within their own unions have increased greatly in both frequency and force since the enactment of the Landrum-Griffin act in 1959. It is public policy, and in my view correct public policy, to encourage democracy in trade unions. However, one disadvantage of the act is that it makes labor leaders less willing to cooperate, in the name of the "public interest," when economic policies are adverse to the interests of their members.

The most difficult union attitude to predict is the reaction to possible tax incentives payable to workers when wage settlements are below guidelines. This carrot approach to the TIP proposal can substitute tax benefits for wage benefits won by a union. Although the individual worker may be unaffected, the benefits are not attributable to the union as an organiza- 
tion and do not win support for union leaders. For this reason, if support of such a plan were voluntary, I would expect that many unions would not participate.

\section{ADMINISTRATIVE PROBLEMS：PRICES}

The Okun proposal is less explicit on the price side than is the WallichWeintraub proposal. In general, Okun proposes that each firm would have to maintain a price index for its domestic products. Many large firms do so now for internal use, though the methods used must be far from uniform and would have to be prescribed. However, the problems of constructing adequate price indexes are far more difficult than those of constructing adequate wage indexes. Most of these problems are well known, and need only to be mentioned briefly. Regulations would be needed to specify how to handle changes in discounts, delivery charges, extras, and similar components of the final price to the buyer. For some products, such as clothing, problems would arise from changes in style. In other cases, such as computers, there would be problems of measuring quality change. Indeed, computers are currently not included in the wholesale price index.

All the difficulties of devising useful price indexes are now dealt with by the Bureau of Labor Statistics in the computation of the consumer and the wholesale price indexes, which is to say that they are generally not insuperable, although few corporations have the statistical competence and resources of the Bureau of Labor Statistics. Moreover, in the absence of a TIP or a price control program, differences of opinion about how to measure prices will not generally give rise to judicial or administrative proceedings; if TIP were in effect, they undoubtedly would.

The agencies that administered price controls had great discretion to omit some products from control by regulation if they did not seem to be important contributors to price increases. This probably could not be done in a TIP that depends on the average price increase of a corporation's products. If exceptions were not possible, the program would have broader price coverage than that of past control programs.

The Okun proposal also calls for a "dollar-and-cents pass-through" of any increases in costs of materials and supplies. This would again entail additional recordkeeping if firms did not maintain separate aggregate measures of the quantity and price of materials purchased. However, the 
administrative problems are small compared to the inequities mentioned earlier arising from the application of uniform price guidelines in the face of sharply divergent productivity trends among industries. The answer might be different price guidelines at the industry level, at least where there are adequate industry measures of productivity, but again this could not be done without administrative machinery.

The claim that TIP requires no new bureaucracy may be true in the sense that it would not require a new government agency. However, it might require the Internal Revenue Service to expand its staff and to recruit personnel with the skills of those at such agencies as the former Cost of Living Council.

One important reason for the strong opposition of business to wage and price controls is that the administrative problems they created absorbed much of the time of corporate officers and required large additional expenditures on legal and accounting services, both internal and external. TIP would probably have similar costs. It is entirely legitimate for TIP proponents to argue that the benefits would exceed these costs, but it is unconvincing to pretend that the costs would not exist.

\section{Deregulation}

The third nontraditional way in which economists have recently proposed to fight inflation is to repeal or modify some government regulations that raise prices or increase costs without creating corresponding benefits. A modest program to seek such changes in regulation was enacted as part of the Council on Wage and Price Stability Act of 1974 and has been in effect for more than three years. However, the success of these efforts has been limited.

Cost-reducing changes in regulations, like cuts in excise taxes, should have a one-time effect in lowering the price level, with gradually diminishing effects on the subsequent rate of change. Such regulatory reform has wide support among economists: those economists who believe that inflation is largely or entirely a monetary phenomenon support deregulation because it would improve the allocation of resources or reduce unnecessary government intervention in the economy.

The business and labor view of deregulation differs sharply from case to case. Any proposal for deregulation is likely to create both groups that 
gain and groups that lose among business firms and employees. To identify these gainers and losers it is useful to distinguish two major styles of regulation, which I call old and new.

\section{OLD-STYLE REGULATION}

By old-style regulation, I mean the kind of regulation exemplified by the Interstate Commerce Commission, which has broad power to set rates or prices and control the entry of firms in a sharply limited industry or set of industries. Many of the agencies that make and administer such regulations are independent commissions outside the cabinet departments. With a few notable exceptions, the general effect of this regulation has been to set prices or rates higher than they would have been without regulation and to limit entry into the regulated industries. In such cases, relaxing the regulation generally tends to lower prices or rates and to increase the quantity of the service supplied.

Proposals for deregulation can be expected to have a mixed reception by business, depending on how a particular enterprise is affected. A few examples will make the conflict of interests apparent.

Some provisions of the 1936 Robinson-Patman act, administered by the Federal Trade Commission, and certain regulations of the Interstate Commerce Commission prevent private carriers of freight from achieving cost savings by carrying freight on return trips, or backhauls. ${ }^{21}$ For example, retailers and wholesalers of food would like to have these restrictions on backhauls removed so that when they make deliveries to food stores they can save freight charges by using their own empty trucks to bring back to the warehouse products manufactured near the destination of the delivery. They understandably complain that empty backhauls waste resources and raise costs. Their efforts are vigorously opposed by the certificated common carriers, who would lose revenue traffic if the restrictions were lifted. These efforts at deregulation are also opposed by some manufacturers of brand-name grocery products who prefer to sell at delivered prices.

In this case, the union representing the affected workers (International Brotherhood of Teamsters) represents drivers for both private carriers

21. Private carriers are truck fleets owned or leased by companies that are not certificated common carriers; these trucks carry goods belonging to the company using the fleet. 
and common carriers and thus may not have a large stake in the outcome. However, the union cannot be expected to support a proposal that might reduce the total employment of its members.

Regulated passenger airlines offer another example of a division between firms now protected and those excluded from regulation. For many years all domestic, regulated carriers opposed deregulation, as did the Air Line Pilots Association. Commuter airlines and charter flight operators favored it, presumably because it would give them access to markets from which they are now excluded. ${ }^{22}$ Recently some reductions in airline fares have been taking place under regulation. This reflects both the pressures created by proposed changes in legislation and the appointment of two economists to membership on the Civil Aeronautics Board.

Domestic interstate natural gas is a leading case in which industryspecific regulation has kept prices below the level that would exist without regulation. In this case, it is the protected industry that seeks deregulation, and the consumer groups that oppose it. Unions generally view deregulation of natural gas from the standpoint of their members as consumers. Deregulation of natural gas would raise price indexes in the short run, but could lower them eventually if the supply response were sufficient to reduce the need to import natural gas.

The events of the last few years suggest that some improvement can be made in those aspects of old-style regulation that raise prices and costs, but progress will come slowly. Regulation that has substantial effects creates large benefits for some segments of the economy. Those segments that receive benefits will naturally fight harder to preserve regulation than the diffuse losers will fight to reform it.

\section{NEW-STYLE REGULATION}

New-style regulation, as exemplified by such agencies as the Environmental Protection Agency, tends to have a narrow focus of concern but a broad coverage of industries. Other examples include the Occupational

22. Among the many anomalies of present airline regulation, I note here that United Airlines is required to serve the eastern Nevada towns of Elko and Ely. In 1970, Elko had a population of 7,621 and Ely 4,176. These locations are served by the smallest plane in the United Airline fleet, a Boeing 737 jet. For a recent discussion of some of the issues raised by air passenger regulation, see Paul W. MacAvoy and John W. Snow, eds., Regulation of Passenger Fares and Competition among the Airlines (American Enterprise Institute, 1977). 
Safety and Health Administration, the Consumer Product Safety Commission, and (with somewhat narrower industry coverage) the National Highway Traffic Safety Administration. Many such agencies are within cabinet departments.

There are many instances in which the costs of new-style regulation seem to exceed their benefits, or where the benefits are not obtained in the least costly way. Again, the reactions of industry and labor to proposals to reduce the cost of regulation depend largely on the particular regulation in question. The automobile industry and the United Automobile Workers have joined in opposing certain costly motor vehicle emission standards. The automobile industry has opposed the mandatory use of air bags to protect the occupants of automobiles in accidents, while the casualty insurance industry has favored it. Industry frequently criticizes OSHA regulations for being too costly, while labor may criticize the same regulations for being too lax.

There is little general understanding of economists' approach to such questions through benefit-cost analysis. The public and legislators frequently argue that life, health, and safety are priceless, and that no cost is too high to pay for them. This is, of course, nonsense, but appealing nonsense. Decisions are made everyday that implicitly place a less than infinite value on life and health-for example, in permitting the use of cigarettes or in constructing a two-lane rather than a four-lane highway. However, opposition to the excessive cost of some new-style regulation is easily depicted as opposition to its worthy purposes.

Better economic analysis could perhaps reduce the cost of new-style regulation without sacrificing desirable objectives. Nevertheless, the aggregate costs of such regulation and its effects on measured prices will probably continue to rise. Perhaps the most that can be accomplished is a deceleration of the rate of increase.

\section{Concluding Comments}

If business and labor oppose some of the new proposals for fighting inflation, particularly the TIP proposals, it is proper to ask whether they would prefer the alternatives. This is not a question they will be eager to answer; it is similar to asking whether one prefers to die by shooting or by hanging. Some guesses about the answer are nevertheless possible. 
It seems clear that labor would prefer TIP to wage and price controls, especially if TIP covered prices. Wage controls are a binding constraint on wages, and unions may pay part of the penalties for deliberate violation of them. In contrast, strong unions might feel confident that under TIP they could exert influence through militant strikes, and that management would take the consequences. By the same token, management might choose wage and price controls as the lesser evil because in return for their costs they might effectively restrain strong unions.

Both unions and management might prefer the use of monetary and fiscal policy to either TIP or controls. A probable exception on both sides of the bargaining table is the construction industry and its suppliers, which under present institutional arrangements in financial markets are particularly vulnerable to increases in interest rates.

The labor movement is on record as being opposed to tight money and high interest rates and as favoring an expansionary fiscal policy. But these policies do not impinge as directly as TIP on the central function of the trade union, which is wage determination. Moreover, labor's view is less crucial to the outcome in this area because the use of monetary and fiscal policy does not require new legislation.

Management would clearly favor the use of tighter monetary and fiscal policies. Although management is now generally willing to concede the need for budget deficits in a recession, it would prefer the budget to be balanced over the full business cycle and strongly questions the need for large deficits in the third year of a recovery.

Business support for tight monetary policy rests both on opposition to inflation and on acceptance of monetarist rather than Keynesian macroeconomic theory. An analysis of the reasons for these views is beyond the scope of this paper, but their strength is not open to question. One element of the explanation may be that business believes neither that the economy is far from full employment at present, nor that there are now large gains in output to be achieved from increased monetary and fiscal stimulus. Keynes did not persuade the business community to abandon the old-time religion, and I doubt that Wallich and Weintraub will be any more successful. 


\section{Comments and Discussion}

Daniel J. B. Mitchell: The Rees paper reviews a variety of policies that might be used to fight inflation. Although he does not state it explicitly, Rees implies that fighting inflation will have to be done-if it is to be done at all-through traditional demand-restraining measures. In particular, he concludes that tax-based incomes policies are currently unacceptable to either labor or management. Moreover, they are administratively complex and possibly unworkable. Rees does not provide a statement of his views on the efficacy of the traditional demand-restraint approach; that is not the topic of his paper. But I doubt that he would expect miracles in the next year or two from monetary and fiscal policies. So I must take this interesting paper to be essentially pessimistic on the prospect of achieving much on the inflation front.

Rees weighs various pros and cons of the TIPs and other recent proposals. Much of his criticism is on administrative grounds. But the paper does not include an explicit statement of the assumed sources of the current inflation or, at least, the reasons for its perpetuation. At present, a justification for a TIP would probably include some reference to institutional factors or inflationary expectations-especially in the labor market -which maintain the momentum of inflation. George Perry's paper in this volume develops this kind of prognosis of the current inflation. If you do not accept such a diagnosis, you probably do not view TIP as a cure.

If the diagnosis is accepted, however, some of Rees' conclusions might be altered. For example, reductions in excise taxes are characterized as "one-shot" affairs. Rees qualifies this characterization by adding that there might be secondary effects but that these effects diminish and eventually fade. The key issue is whether or not the rate of inflation is lower after the absolute price level effects have worked through the economy. 
In some views of the momentum of inflation, it is possible that a permanent reduction in inflation could be made by a coordinated series of seemingly one-shot policies. Much depends on packaging. A cut in an excise tax might be put forward as a minor technical fiscal adjustment. Or, alternatively, such cuts might be presented as part of an overall anti-inflation program. If the latter could be made convincing, the rate of inflation might be permanently lowered, either by affecting expectations or by influencing other aspects of the wage-price setting process that might be responsible for the momentum of inflation.

The same can be said for the type of interventions in the federal regulatory process that the Council on Wage and Price Stability regularly attempts. Taken one at a time, a tilt at the Occupational Safety and Health Administration or at the Civil Aeronautics Board will have little perceptible impact on inflation, although these interventions might be justified on resource allocation grounds. (Such tilting does have the advantage of keeping the council in business when fighting inflation is not in vogue.) But as part of a publicized anti-inflation package, the impact on inflation could be more lasting. Indeed, I had always assumed that the council, under Rees' initial direction, had something like this in mind when it launched its activities in 1974.

Because much of the fault Rees finds with TIP proposals is directed toward administrative considerations rather than the theory of inflation, most of my remarks will focus on the administrative issue. His basic position-one with which I am totally in accord-is that in many ways a TIP would be no simpler to operate than a formal controls program. All the problems of costing, base periods, unforeseen effects, and so on associated with controls arise under TIP. The advocates of TIPs have often underestimated the inherent complexities, and it is useful for Rees to point these out. In effect, Rees tells us that the choice between controls (formal or informal) and TIP should not be made on the assumption that TIP will be simple to administer. But there are other grounds for favoring TIP over controls.

TIPs are said to avoid or minimize two important drawbacks of controls. First, in the labor market, controls invite confrontations between unions and government authorities when specific, newly negotiated contracts are reviewed. Such confrontations can discredit a policy if the guidelines are openly flaunted (as in the example of President Johnson and the airline machinists) or the authorities appear to buckle (President Carter's 
deceleration and coal intervention). Second, controls can create "distortions" of misallocation and shortages, primarily in the product market. TIPs leave collective bargaining to the parties, thus avoiding direct government involvement and reducing the risk of confrontation. And the product-market misallocation that might be created is likely to be less severe under TIP than under rigid pricing rules or ceilings. Rees does not seem impressed by these arguments, but they make sense to me.

Although I agree that controls and TIPs involve similar administrative problems, I believe the Rees paper overestimates the complexity of these problems. Consider the issue of establishing guidelines. Rees takes us over the familiar ground of productivity-based guidelines and the usual arithmetic that wage changes equal productivity plus inflation. Productivity plus inflation has been a convenient rationale for justifying the wage goal of past policies. But the rationale is not that important. Indeed, the goal and the guideline need not be synonymous. Much depends on the nature of the policy. If a controls policy permits few exceptions or a TIP policy imposes stringent penalties, the guideline must be higher than the goal. The more liberal the program, the closer the guideline is to the goal.

An explicit productivity guideline, as Rees notes, raises the specter of a "frozen" income distribution. But such fears are exaggerated. The purpose of incomes policies, tax-based or otherwise, is not the redistribution of income-despite the misleading nomenclature-but rather the reduction of cost increases. ${ }^{1}$ The goal and guideline should be set high enough to be realistic, but low enough to reduce inflationary expectations. If a productivity rationale confuses the issue, then deceleration or some other rationale can be offered. ${ }^{2}$

1. The term "incomes policy" began to be used in Britain in the early 1960s for several reasons. First, it was more politically appealing than "wages policy," the earlier term. Second, the British were beginning to flirt with economic planning, and the notion of planning incomes seemed enticing. Third, in Britain and elsewhere in Europe, the view that inflation results from deficient saving propensities of the working class relative to capitalists is popular with both left-wing and right-wing observers. Hence, incomes rather than costs are often seen as the target of a controls policy.

2. As long as setting guidelines is viewed as an art rather than as a science, the inflexibility of a numerical guideline cited by Rees need not occur. The 5.5 percent guideline of the 1971-74 program, although rationalized along the lines of productivity plus inflation, was the result of a bargaining process at the Pay Board. It remained inflexible after Phase II simply because the new authorities chose to deemphasize the guideline approach altogether; to change the guideline would have implied recognition of its importance. 
Probably the most important arguments Rees raises on the administrative side are in the area of industrial relations. He points out that bargaining units are not the same as tax units. A bargaining unit may be a part of a larger tax unit (for example, unionized blue-collar workers but not white-collar workers) or it may be composed of many tax units (multiemployer bargaining and pattern-following situations). Variations in the occupational and age structure among firms in a multiemployer unit may lead to different cost and tax consequences under TIP.

I think the unit problem is a strong anti-TIP argument. But there is another side that should be noted. Traditional monetary and fiscal policies may also have differential consequences for firms in a multiple-employer bargaining unit or pattern. When faced with economic pressures and technical change, bargaining units sometimes dissolve, as occurred in the glass industry in the 1950s. The differential pressures on members of bargaining units may lead to divergent treatment without destroying industrial relations. (American Motors received concessions from the Autoworkers as did Studebaker before it.) When there are multiple wage-determination units within a firm, the different units are always competing with each other to some extent for their relative shares. A TIP may exacerbate these problems, but it does not create them.

Rees also points to industrial disputes as a potential problem of TIP. Stiffening the backbone of management, he notes, might cause more strikes. In some versions of Arthur Okun's reward TIPs, this would not be an issue. But even under penalty TIPs, whether or not this tendency is thought to be significant depends on the model of the bargaining process that is applied. On the one hand, if strikes are brought about by collisions of inflexible and incompatible demands, anything that widens the spread between labor and management will cause more strikes. On the other hand, if strikes are the results of mistaken judgment about the points of resistance of the other party, the tendency of TIP to increase strikes need not be pronounced. It is likely, however, that whatever the true effect might be, strikes that lead to significant public inconvenience would be blamed on the program.

I am puzzled by Rees' insistence that the proponents of TIPs must inherently believe that unions maximize some specific goal in negotiations. ${ }^{3}$ All that is assumed by TIP advocates is that management resis-

3. Rees is critical of the Wallich-Weintraub diagram that shows labor and management positions converging. There have been empirical studies that track the posi- 
tance plays a role in bargaining outcomes. If bargaining were simply a process by which unions put forth nonnegotiable demands and management had to accede, wages would be high indeed, and strikes would be nonexistent. Rees states that there will be cases in which the TIP guidelines would cause the size of the eventual settlement to be smaller. Are TIP proponents really assuming anything other than that?

Finally, Rees' overall conclusion that neither labor nor management is likely to favor either controls or a TIP is not surprising given recent history. But neither is it decisive. Both parties have had the recent experience of controls, and found it distasteful. To the extent that the TIP proposal is known outside the narrow world of economic academia and Washington policymakers, it is undoubtedly seen as another form of controls. Yet it is apparent from the 1971-74 experience that such attitudes are not irrevocably fixed. In early 1971, organized business promoted controls, and organized labor was at least unopposed to the notion. Even after the labor walkout from the Pay Board in early 1972, AFL-CIO President Meany said that labor would learn to live with the regulations. In late 1972, when the shift to Phase III was under debate, organized business did not support rapid decontrol. It was during 1973-74, when the authorities persisted in trying to hold back the tide started by the food and oil price increases, that the opposition of business and labor hardened.

Both formal controls and the TIP proposals require congressional action. Congressional debate would have a destabilizing effect on wages and prices. The TIP proposal, in addition, would put an added burden on an already complex tax system. For those reasons, I share Rees' doubts about the various TIP proposals, even apart from the administrative issues he raises. But I am not persuaded, as he seems to be, that attitudes toward all forms of direct intervention cannot be changed. In particular, I am not certain that the prospect of another recession would not be a powerful factor in stimulating a rethinking conceming some sort of social compact on the part of organized labor. The fact that management readily supports demand restraint could well encourage union leaders to reconsider the alternatives.

tions of the parties in particular negotiations and come up with curves that look something like that diagram, although they are not as linear. Of course, it is impossible to record the "true" goals of the parties as opposed to the "feelers" they extend. See Roger L. Bowlby and William R. Schriver, "Bluffing and the "Split-the-Difference' Theory of Wage Bargaining," Industrial and Labor Relations Review, vol. 31 (January 1978), pp. 161-71. 
Lloyd Ulman: In principle, incomes policies may be divided into two categories: those that restrain wages directly and prices indirectly, and those that restrain prices directly and wages indirectly. (In practice, of course, most policies contain elements of both types.) Each type of policy has often been accompanied in recent years by compensatory modifications of tax policy. Policies of direct wage restraint have been combined with reductions in income or excise taxes to compensate wage earners for gains forgone under collective bargaining; and price controls have been accompanied by reductions in various types of business taxes or by extension of subsidies to protect profits and investment, to minimize industrial strife due to stiffened employer resistance, or both.

Incomes policies of both types have entailed economic or social costs that have limited their effectiveness, either by weakening compliance by the parties at whom they have been directed or by weakening the political will of the community to enforce or even to introduce them. Economic costs involve misallocation and other types of inefficiency and, ultimately, slower growth rates. Social or political costs result from abridged freedom, where the policies are in fact backed by legal sanctions. Acrossthe-board tax reductions may prove to be inefficient incentives to wage restraint (and hence inadequate substitutes for legal sanctions) because they are not conditioned on compliance in each wage-determining situation. And if direct policies of wage restraint are to be effective, they would remove from the unions a great part of their raison d'être (a greater part than private enterprise would lose from price controls).

The case for tax-oriented incomes policies is that they are free of the defects of other types of incomes policy, and, consequently, that they are inherently more efficient in improving the inflation-unemployment tradeoff. They presume an inducement-negative or positive-to restrain at the least centralized levels of wage determination as well as at the most centralized ones. (This minimizes the probability that restraint exercised at formal, centralized negotiations would be neutralized by greater wage drift at the plant level, which is what allegedly occurred in Sweden after a reduction in income taxes in 1975.) The unions would not be stripped of their wage-bargaining function because they and the employers would be legally free to bargain for increases above the norm if it were profitable to incur the tax penalty or forgo the tax benefit for doing so. For the same reason, there is no abridgment of economic freedom. Nor would the operation of TIPs cause serious misallocations or inefficiencies because 
if compliance would cause them, the employer would have the incentive and the freedom to disregard the wage norm. TIP, in short, would be at once less restrictive and arbitrary and more effective than controls.

"Spinach!" cries Professor Rees, whose task it is to anticipate and evaluate the reactions of unions and of employers. He is led to the view that TIP, in practice, would be no less, and possibly more restrictive and arbitrary than conventional controls, and no more effective than conventional controls. Several points should be mentioned regarding the implementation of TIP. First, the restricted coverage contemplated for penalty TIPs requires a more direct and mandatory wage restraint in such areas as state and local governments, nonprofit institutions, and small firmswhere, as Rees points out, the building trades, teamsters, and other strong unions are organized. Wallich and Weintraub recognize that coverage must be restricted, but imply that exemptions can safely be made. However, if relative wages were raised significantly outside the area of coverage, that would threaten the viability of TIP where it is supposed to apply because various traditional wage patterns cut across the boundaries defining the area of coverage.

Second, the implementation of TIP might prove to be less impersonal and automatic than the implementation of controls and, to that extent, no less abridging of freedom. (To identify freedom with legal liberty is to mistake a part for the whole.) Definitional and computational problems, as outlined by Ackley and Rees, might arise in specific situations; and, while they would be neither unique nor insoluble, their resolutions would require interpretation, the exercise of discretion, and, therefore, bureaucracy.

Guidelines would have to be set for TIP; at least in Okun's version of TIP, these would include price guidelines as well as wage guidelines. I agree with Rees that price guideposts would be both a political and an economic necessity. I would go further in one direction than Rees does in his discussion of wage norm issues and not as far in another. In my view, a TIP guidepost should provide full compensation for the prospective rate of inflation. TIP is logically and admittedly designed to cope with only the cost-push component of inflation-which would slow along with wages-and the government should ensure that inflation from other sources does not erode real wages. Aggregate demand policy must avoid excess demand. And government policies in other areas must concern themselves with price stability. Without those additional policies, under 
a "low" wage norm real wages would fall relative to trend productivity. Such a program would be difficult to achieve; and trying for it could even yield a perversely restrictive effect on aggregate demand as a result of large penalty taxes imposed under TIP. Achieving it would depend on a mixture of persuasion and legal sanctions characteristic of conventional incomes policies, in addition to the tax disincentive. Such a low, downward-ratcheting norm for wage increases could be established and periodically reestablished only under a political process that has come to be known as "big-gun bargaining," which involves the labor movement, some type of management ball team, and the government.

I would not go so far as Rees in holding that TIP requires a norm for wage increases, while an effective system of controls would not. A norm admittedly entails two disadvantages. First, it can act as a red flag for some of the otherwise more resigned or contented bulls in the pasture. Despite this, its net effect might still be to restrain wage behavior, especially if it serves as a signal for moderation to nonunion firms and if it can serve as a scapegoat for some union leaders who might otherwise press for excessively rich settlements against their own better judgment. Second, it is difficult to develop a norm that would allow room for justifiable "exceptions" without sacrificing clarity or signaling efficiency. But these problems also exist for controls. Under controls, the authorities must have some wage or price targets in mind; and these cannot long remain classified information. A system of controls, whether legal or de facto, could operate with a more obscure central guidepost than a TIP system. However, it is not true that TIP needs a guidepost that controls can avoid altogether.

Rees also claims that a TIP would probably "increase both the frequency and the duration of strikes," whereas controls act as an effective deterrent to striking. Wallich and Weintraub question the former proposition. They argue that the prospect of a penalty tax increase could discourage unionists from striking by stiffening the employer's backbone, and thus reducing the prospective gains from a strike. Seidman claims that a TIP with a carrot approach-a payroll tax credit for employeeswould reduce the incentive to strike for and obtain wage increases above the norm; to strike, he contends, would deprive employees of the tax credit for marginal increases above the norm and also for all increases up to the norm.

It is useful to distinguish among three components of bargaining power 
in assessing strike prospects: (1) maximum, or potential, bargaining power, which would maximize the increase in the employer's labor costs, given the market conditions that determine the employer's ability to pay and to resist and given various determinants of the goals and militancy of the union's members; (2) desired bargaining power, which reflects membership attitudes but other things as well and is reflected in the demands by the union's negotiators and leadership; and (3) actual bargaining power, or the actual results of collective bargaining. The question of how TIP would affect bargaining cannot be answered a priori. A TIP penalty tax would increase employer resistance, but if unions were not exploiting their maximum bargaining power, the tax stick would neither discourage unions from striking nor result in reduced settlements. This is consistent with Rees' observation: "When the union has the power to win a long strike, it does little good to strengthen management's backbone." It is indeed possible that a tax penalty would in fact reduce a union's bargaining potential below previously achievable target levels. But if the target levels were maintained, or not reduced in proportion, union dissatisfaction would be increased and so would strike activity, although actual negotiated increases would presumably be reduced. Seidman's tax carrot is designed to reduce bargaining targets, but it will prove tempting only if the wage norm under TIP is sufficiently high relative to the union's target to make the difference between the two less than the probable costs of striking for the target. There is no presumption that a given norm will be consistent with the achievement of the two policy targets of price stability and industrial peace.

These possibilities illustrate another characteristic that TIP shares with other forms of incomes policy, including controls: the levels of performance that can be specified and achieved through enforcement are governed by the public, by political tolerance of industrial disputes, by the more narrowly economic cost of enforcement, as well as by tolerance of unemployment and inflation. But if more strikes and the winning of strikes by unions are to be counted as a cost of TIP, that cost must be weighed against an institutional gain, which helps distinguish TIP from other wage-restraint policies. TIP does preserve a role for union bargaining. In this respect, TIP brings to mind the theoretical basis of the Swedish active labor market policy, which was designed to reduce aggregate money demand relative to output and hence to increase the resistance to union demands by employers who were subject to constrained profit margins. 
This method was developed by the chief union economist of the Swedish Federation of Trade Unions in the aftermath of an unsuccessful incomes policy.

Despite the advantage of preserving a role for collective bargaining, the prospect of more or longer strikes under TIP may not enhance its prospects of acceptance by the general public, management, or the unions. But it is worthwhile asking what order of magnitude the cost of additional strikes is likely to be. Since World War II, only a little less than a quarter of 1 percent of working time has been lost due to industrial disputes. Moreover, the economic costs of strikes are often estimated without netting them against any gains that they generate in the form of smaller increases in costs and prices. On the premise that one New Yorker cartoon deserves another, I recall one in which the chairman of the board complains to his fellow directors, "We haven't had a strike in ten years. We must have been overpaying them all along." If TIP increases strikes, with the added social and economic costs, it should also increase the associated gains.

The criterion implied in the last statement should be expanded to include other costs associated with TIP, including bureaucratic costs. I concur with the view that TIP is not a "free policy lunch." It is not totally free of the costs attributable to a conventional system of controls; nor is its effectiveness independent of the level of its acceptance in principle by labor and management. One question to be asked is whether a TIP with controls and persuasion is more cost-effective, in the broadest sense, than a system of controls with persuasion but without TIP. This question cannot be answered a priori.

In my opinion, a system with a selective and discriminating tax incentive is preferable to one without it. Given general acceptance, such a tax incentive should prove an effective way to penalize the rogue elephant or to deter others from straying from the herd. For the same reason, the use of discriminating tax reductions may be preferable to across-theboard reductions, unless the latter can be conditioned on restraint by wage (and price) setters. The prospects for contingent tax reductions are limited by two considerations. First, in a system of decentralized wage determination, individual units cannot readily afford to be guided by macroeconomic considerations. Second, some of the most powerful groups of workers are, almost by definition, least likely to suffer the consequences in reduced employment flowing from the exercise of their 
power. The authorities, representing the general public-including the minority groups that are weakest economically - are unfortunately not in a strong position in this big-gun bargaining encounter. They are not in a position to condition expansionary tax reductions on wage restraint because their desire for high levels of employment may well exceed even that of powerful unions. In this general respect, therefore, TIP is preferable to general tax reductions precisely because it is inherently contingent on prior wage restraint.

\section{General Discussion}

Several participants in the discussion differed with Rees' characterization of the bargaining process. Sidney Weintraub said that Rees had assigned union leaders too large a role and that he had neglected the part played by union members and the labor movement in general. Rees replied that union leaders tended to be more restrained than their membership. It was the membership that had broken wage guidelines in the past by rejecting settlements reached by the leadership. He favored union democracy but pointed out that it increased the pressure on union leaders to produce larger gains at the bargaining table. Martin Baily argued that Rees had overemphasized the union sector and a particular model of wage settlements in that sector. Even if a maximization model is not accepted as appropriate, competitive pressures impinged on the bargaining process. The majority of the labor force is not unionized, and wages in the unionized and nonunionized sectors affect one another directly. In addition. there are indirect influences through the product markets and through the option of unionized firms to produce something in-house or to subcontract it to smaller, nonunion firms.

Laurence Seidman observed that a TIP scheme might have a substantial impact on the firms that Rees had said would not be influenced by TIP. Even though an unprofitable firm might not be directly affected by a penalty TIP on profits, the knowledge that TIP would make its profitable competitors resist a high-wage settlement would lead it to be tougher in its own wage negotiations. Even aggressive unions with sufficient market power to ignore TIP would discover that their real or relative wage objectives could be achieved with lower wage increases if wages elsewhere were affected by TIP. 
Baily and Seidman both disagreed with Rees' assertion that management's aggressiveness would not be seriously strengthened by TIP. They said that management's resistance would depend on the cost of settlements, and management's opposition to each proposed wage increase would now be greater.

Weintraub suggested that additional features could be added to TIP to meet some of Rees' objections. In particular, some way could be found to encourage wage resistance by firms that were incurring losses and therefore were not subject to profits tax. He also noted that the government could augment TIP effects by contracting only with firms that had adhered to wage rate standards. He noted that the Davis-Bacon act already constituted a form of incomes policy on government construction. Rees added that by changing the administration of the Davis-Bacon act so that the prevailing wage was the median wage in any market, wages mandated by the act would be substantially reduced. But this has never been done because it is too costly politically.

Michael Wachter found both start-up problems and ongoing problems with TIP. Because the wage structure is always in disequilibrium, starting up a TIP program unfairly penalizes those wages coming up for new settlement. Furthermore, the government frequently has a stake in collective bargaining outcomes and becomes involved in such negotiations through the Federal Mediation and Conciliation Service. TIP could place the government in the position of inducing a settlement and then taxing the outcome. But Charles Holt replied that one important benefit of TIP would be to take the government out of the collective bargaining business.

Wachter also noted that TIP differed from controls only in degree, so that it risked the same problems of misallocation on the one hand or of being discredited by excessive settlements on the other. Seidman replied that although a TIP with a prohibitive tax on high settlements would be equivalent to controls, a TIP with a reasonable penalty had the advantage of allowing the necessary relative wage adjustments to take place. However, Lloyd Ulman cautioned that it might not be possible to allow the required relative wage changes and meet a particular inflation objective at the same time.

Seidman reasoned that labor's fears that TIP would be biased against labor's share of income could be allayed by "real wage insurance" rather than treated as an insurmountable obstacle. Baily argued that income shares were an inadequate measure of labor's well-being and that the 
record showed that controlling inflation was good for labor. From 1950 to 1969, labor's share had declined, but real gross earnings had risen 16 percent. In the 1970s, its share had increased, but real earnings had not risen. George Perry added that labor's resistance to a penalty TIP would almost certainly be greater than its resistance to a reward TIP. Politicians who did not want to vote to penalize wage gains could hardly be equally persuaded not to reward socially desirable wage behavior.

Charles Holt felt that Rees had concentrated too narrowly on the role of a penalty TIP in stiffening the backbone of management and thought most problems with the details of a TIP plan could be solved. He offered his own employee-oriented TIP, with a target range within which wage adjustments would not be affected (to allow room for necessary relative wage changes) and with rewards and penalties for wage changes below and above the range. 